\title{
TREATED DIATOMITE FOR TOLUIDINE BLUE REMOVAL FROM WASTEWATER. IS IT WORTH IT?
}

\author{
ANDRADA S. MĂICĂNEANU ${ }^{a *}$, RALUCA PLEȘA CHICINAȘ ${ }^{b}$, \\ HOREA BEDELEAN ${ }^{c}$
}

\begin{abstract}
The adsorption of Toluidine Blue (TB) cationic dye was performed using raw and treated (thermal, chemical, thermo-chemical, ultrasonic) diatomite. Solid samples were characterized using X-ray diffraction (XRD), scanning electron microscopy (SEM), X-ray photoelectron spectroscopy (EDX), and Fourier Transformed Infrared Spectroscopy (FTIR). Adsorption experiments were performed in batch conditions $\left(20 \pm 2^{\circ} \mathrm{C}, 100 \mathrm{mg} \mathrm{TB} / \mathrm{L}, 100 \mathrm{~mL}, 0.1 \mathrm{~g}\right.$ adsorbent). The best sample proved to be the one thermally treated at $250^{\circ} \mathrm{C}$ for $2 \mathrm{~h}$ with an adsorption capacity of $7.97 \mathrm{mg} / \mathrm{L}$ and $77 \%$ removal efficiency. The regeneration process of the used diatomite was also performed (calcination, $\mathrm{HCl}$, water), the most efficient was the one using water. Kinetic models (pseudo-first-, pseudo-second-order, liquid film, and intra-particle diffusion) were considered to describe the experimental data. The calculated data showed that liquid film diffusion might be rate-determining step in this case.
\end{abstract}

Keywords: diatomite, adsorption, toluidine blue, regeneration, kinetics

\section{INTRODUCTION}

Industrial activities such as textile, cosmetics, pulp and paper, plastic, paints, printing, leather, pharmaceuticals, food, and mineral processing are all discharging wastewaters with a high content of dyes $[1,2]$. Wastewater treatment, based on physical, chemical, or biological processes, such as coagulation, flotation, adsorption, chemical oxidation, filtration, ozonation, ion-exchange, and aerobic and anaerobic microbial degradation, were all

\footnotetext{
a Madia Department of Chemistry, Indiana University of Pennsylvania, Indiana, PA 15705, USA

b Ana Aslan Technical College, 41 Decebal st., 400124, Cluj-Napoca, Romania

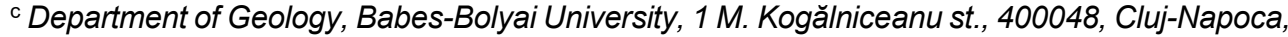
Romania

*Corresponding author: sanda.maicaneanu@iup.edu
} 
considered for dye removal from wastewater. Between the available methods, adsorption has proven to be effective and convenient and activated carbon the adsorbent used with the best results. Due to the high costs involved in its regeneration, low-cost substitute materials were considered $[1,3,4]$.

There are many studies which have shown that numerous natural and inexpensive materials were successfully applied in the removal of dyes from wastewaters, such as coal, wood powder, lignin, shale oil ash, zeolite, perlite, clay minerals, diatomite, activated slag, activated carbon, fly ash, and agricultural wastes [3-5].

The most important property of an adsorbent is the surface area and structure. Any solid material with a microporous structure and a large surface area can be used as adsorbent. Diatomite is one of the materials which fulfils these conditions $[6,7]$.

Diatomite is a fine, siliceous natural rock, composed mainly by microscopic frustules (skeletal remains) of silica microfossils of dead diatoms, radiolaria, and sponges. Most diatoms are elongated (pennate diatoms), while others are round (centric diatoms). The main component of diatomite is amorphous silica $\left(\mathrm{SiO}_{2} \cdot \mathrm{nH}_{2} \mathrm{O}\right)$. Sometimes the siliceous deposits may be pure, sometimes they are mixed with clay, carbonates, or organic matter. It's a pale-colored, soft, light-weight sedimentary rock, with $80-90 \%$ voids in its structure [6-8].

Diatomite has numerous physical and chemical properties that are important for the adsorption process, which include high porosity, high permeability, small particle size, high surface area, and low thermal conductivity. All these properties make diatomite a low-cost alternative to activated carbon, suitable for many industrial applications such as filtering and adsorption of organics and heavy metals from wastewater $[6,9,10]$. Diatomite surface is terminated by $\mathrm{OH}$ groups (will form hydrogen bonds with the adsorbate) and oxygen bridges, which act as adsorption sites [11].

Not many studies considered the influence of various treatments on adsorptive (organic compounds) properties of diatomite. Aivalioti et al. [12,13] studied BTEX, MTBE, and TAME adsorption on raw, thermally, chemically (acid), and both chemically and thermally treated diatomite, with the sample treated with $\mathrm{HCl}$ being the most effective [13]. Dye and printing wastewaters were used to test adsorptive properties of diatomite treated with $\mathrm{HCl} 5 \%$ followed by calcination at $500^{\circ} \mathrm{C}$ [14]. HF etching (various concentrations, time of reaction, temperatures) was proved to drastically change the porous structure of diatomite and therefore adsorptive properties towards methylene blue [15]. Thermo-chemical treated diatomite $\left(\mathrm{H}_{2} \mathrm{SO}_{4} 5-6 \mathrm{M}, 900^{\circ} \mathrm{C}\right)$ was used 
to remove methylene blue from aqueous solutions, two studies indicating that this type of treatment improves its performances as adsorbent $[16,17]$. Diatomite subjected to a $\mathrm{NaOH}$ treatment proved to improve its adsorptive properties towards methylene blue adsorption [18].

The aim of this study was to explore the use of Romanian pennate frustules diatomite as adsorbent for toluidine blue (TB) dye removal from aqueous solution and to decide if the treatments applied to the raw diatomite are justified. Reutilization of the spent diatomite after regeneration was also considered. As treatment applied to diatomite are likely to modify its porous structure, kinetic models (pseudo-first-, pseudo-second-order, liquid film, and intra-particle diffusion) were considered to describe the experimental data.

\section{RESULTS AND DISCUSSION}

\section{Adsorbent characterization}

The diatomitic ore from Minişu de Sus, the most important one in Romania, is located in the western part of the country, in Arad County. It is of Sarmatian age and it is positioned within the lower tuffaceous diatomitic complex. Diatomite layers are usually interbedded with clays, limestone as thin intercalations, as well as with silts, sands, and pyroclastic material. The diatomite from Minişu de Sus may be characterized as clayey diatomites as it contains some amounts of smectitic clays, whereas the presence of calcite or other carbonate mineral is negligible. The white-yellowish diatomite consists mainly of a mixture of small elongate frustules of pennate diatoms, clay minerals, and amorphous silica. The pennate type of diatoms gives the material superior technical properties, compared to those constituted from centric forms [8].

$X$-ray diffraction analyses performed on random powders indicate the presence of silica minerals as the main component (Figure 1). The highly crystalline peaks of cristobalite and quartz could be observed. The presence of biogenic opal $A$ (amorphous silica) is indicated by a slightly broad reflexion centered at $2 \theta=20-25^{\circ}[19]$ and well crystallized quartz. The quartz crystals are even allogenic, of a volcanogenic origin, or formed from the devitrified glass. Smectitic clay minerals (montmorillonite) and feldspars are also present but in small amounts. 


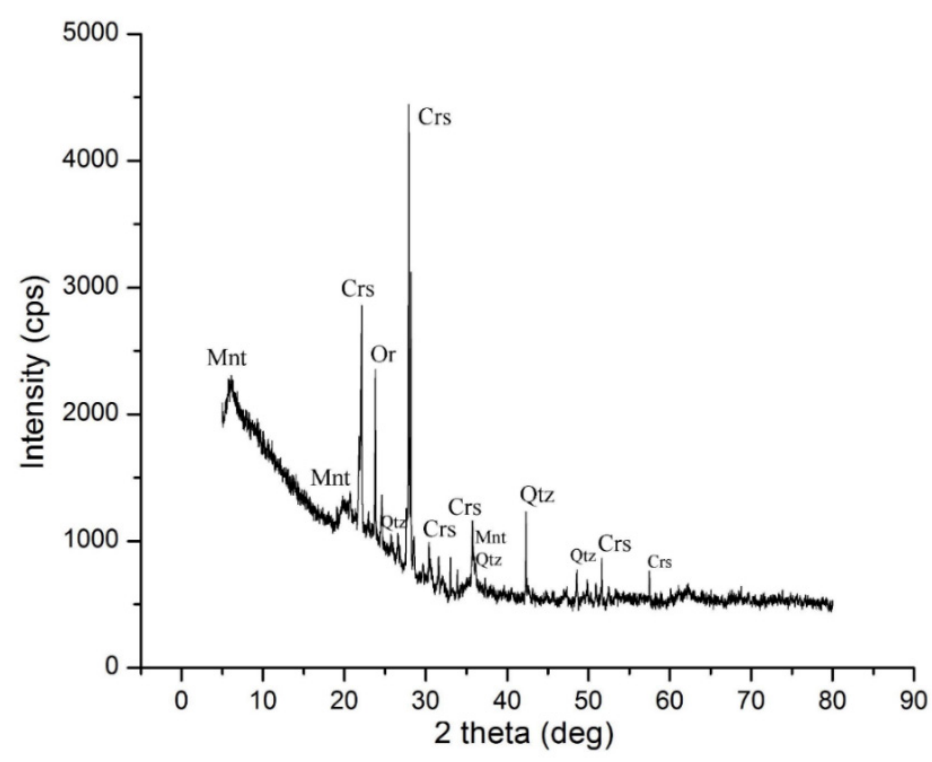

Figure 1. XRD pattern of raw diatomite (D) from Minișu de Sus (Arad County, Romania). Legend: $\mathrm{Crs}=$ cristobalite, $\mathrm{Mnt}=$ montmorillonite, Or = orthoclase, $\mathrm{Qtz}=$ quartz

SEM analysis provides data on the morphology of diatoms and on the porosity of the material. The images revealed the presence of the pennate frustules of diatoms with open-pores dispersed in clay matrix (Figure 2). The porous structure can be observed. Pores and open voids provide natural filtration and adsorption properties to the diatomaceous material.
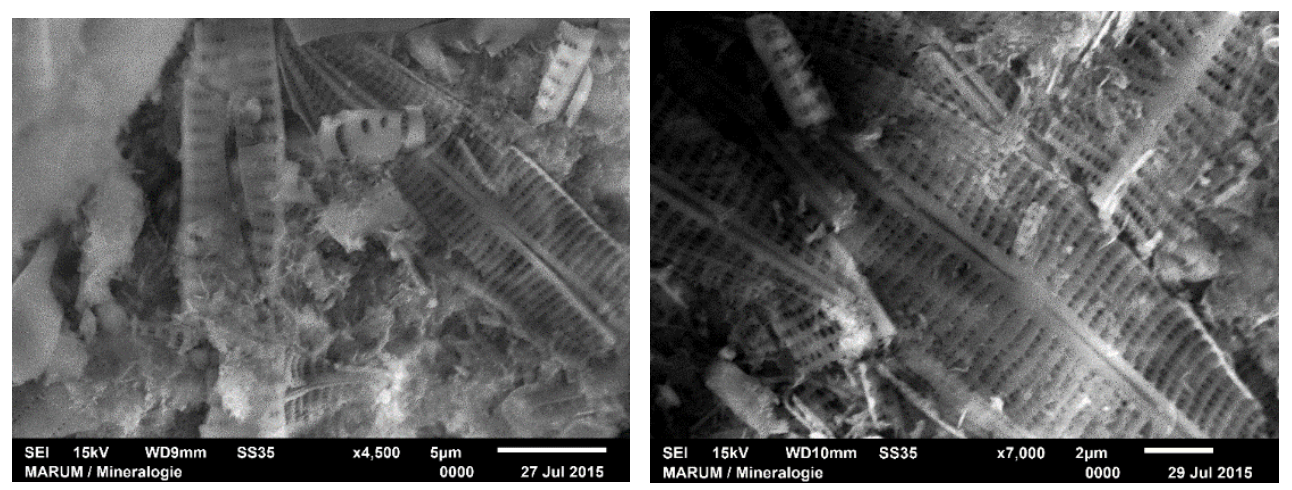

Figure 2. SEM images of raw diatomite (D) from Minișu de Sus (Arad County, Romania). Fragments of pennate diatoms frustules hosted in a clayey matrix. 
The chemical composition of the diatomitic material varies, due to the lithological heterogeneity of the ore [8]. $\mathrm{SiO}_{2}$ is the main oxide, between 65$76 \%$, constituting the diatom frustules, opal- $\mathrm{A}$ is present in the cement, while detrital quartz and silicates (feldspar, clay minerals) are also present. $\mathrm{Al}_{2} \mathrm{O}_{3}$ has average values between 5-19\%, being found in feldspars and clay minerals. $\mathrm{Fe}_{2} \mathrm{O}_{3}$ is contained mainly by iron oxi-hydroxides and varies between $3-7 \%$. CaO is in small amounts, between $2-6 \%$. It is present in plagioclases, montmorillonite and probably in secondary carbonates. According to the $\mathrm{SiO}_{2}: \mathrm{Al}_{2} \mathrm{O}_{3}$ ratio, the diatomites for Minișu de Sus belong to the clayey-type. From the EDX spectra of the considered diatomite sample (D) (Figure 3), the atomic elemental composition in wt. \% was depicted as follows: $64.6-\mathrm{O}$, $26.5-\mathrm{Si}, 5.69-\mathrm{Al}, 1.12-\mathrm{Ca}, 0.98-\mathrm{Fe}, 0.64-\mathrm{Mg}, 0.26-\mathrm{Na}$ and $0.15-\mathrm{K}$ (the difference up to $100 \%$ corresponds to gold used for sample preparation).

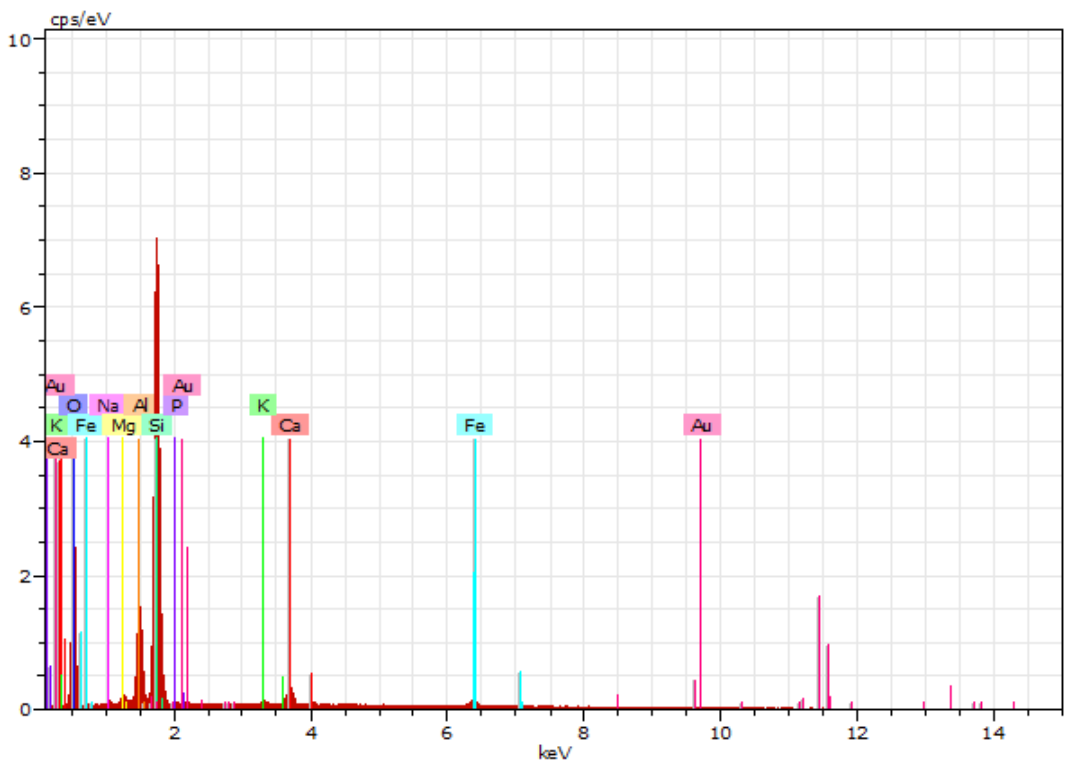

Figure 3. EDX spectra of raw diatomite (D) from Minișu de Sus (Arad County, Romania).

The FTIR spectra for raw diatomite and some of the treated samples (the ones which were giving the best results in terms of dye removal efficiencies) are presented in Figure 4. The main bands indicated the presence of diatomite specific peaks, Figure 4 and Table 1. All the samples present similar spectra with a slight increase in the intensity in case of thermal and thermo-chemical treated samples. The bands at $3625-3630 \mathrm{~cm}^{-1}$ are attributed 
to Si-OH stretching. The bands in the $3440-3443 \mathrm{~cm}^{-1}$ range are characteristic to $\mathrm{O}-\mathrm{H}$ stretching vibration, while the $1636 \mathrm{~cm}^{-1}$ band is characteristic to $\mathrm{H}-\mathrm{O}-\mathrm{H}$ bending of adsorbed water molecules. The 1093-1094, 795-797, and 467$468 \mathrm{~cm}^{-1}$ bands are characteristic to $\mathrm{Si}-\mathrm{O}-\mathrm{Si}$ asymmetric stretching, Si-O-Si symmetric stretching and Si-O-Si / Si-O-Al bending, respectively [20-23].

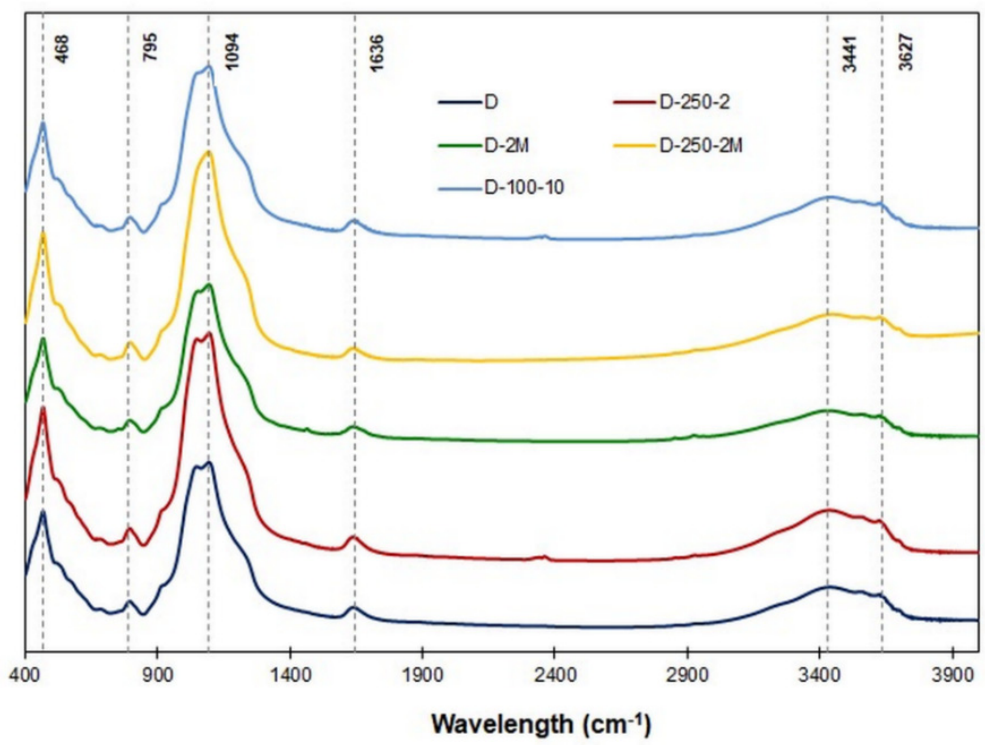

Figure 4. FTIR spectra of D, D-250-2, D-2M, D-250-2M, and D-100-10 diatomite samples.

Table 1. Most relevant infrared spectral bands of the D, D-250-2, D-2M, D-250-2M, and D-100-10 samples [20-23].

\begin{tabular}{|c|c|c|c|c|c|c|}
\hline Sample & D & $D-250-2$ & D-2M & $D-250-2 M$ & D-100-10 & Assignment \\
\hline \multirow{6}{*}{ 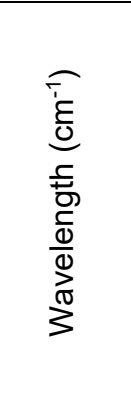 } & 468 & 467 & 468 & 467 & 467 & $\begin{array}{l}\mathrm{Si}-\mathrm{O}-\mathrm{Si} / \mathrm{Si}-\mathrm{O}-\mathrm{Al} \\
\text { symmetric bending }\end{array}$ \\
\hline & 795 & 795 & 796 & 797 & 796 & $\begin{array}{c}\mathrm{Si}-\mathrm{O}-\mathrm{Si} \\
\text { symmetric stretching }\end{array}$ \\
\hline & 1094 & 1094 & 1094 & 1093 & 1094 & $\begin{array}{c}\text { Si-O-Si } \\
\text { asymmetric stretching }\end{array}$ \\
\hline & 1636 & 1636 & 1636 & 1636 & 1636 & $\mathrm{H}-\mathrm{O}-\mathrm{H}$ bending \\
\hline & 3441 & 3440 & 3440 & 3444 & 3443 & $\mathrm{O}-\mathrm{H}$ stretching \\
\hline & 3627 & 3626 & 3626 & 3625 & 3630 & Si-OH stretching \\
\hline
\end{tabular}




\section{Adsorption results}

For each considered treatment applied to the raw diatomite sample, maximum removal efficiencies were considered and compared. In the case of thermally treated samples, Figure 5a, a small increase in removal efficiency, from 71 to $77 \%$, was observed for D-250-2 sample. This fact might be attributed to the fact that as the temperature increases water is removed from the solid surface, making pores more accessible. Further increase of the temperature led to partial collapsing of the porous structure [24] and therefore to a decrease of the surface available for adsorption, hence a decrease of removal efficiency to $58 \%$ recorded for $D-750-2$ sample. When calcination time was increased from 1 to 4 hours at $500^{\circ} \mathrm{C}$, the decrease in removal efficiency was constant irrespective to the calcination time (71 to $57 \%$ ).

When chemical treatment was considered, Figure $5 \mathrm{~b}$, a slight increase in removal efficiency was observed for D-2M sample (from 71 to $76 \%$ ), while with a further increase of the $\mathrm{HCl}$ concentration, $\mathrm{D}-4 \mathrm{M}$ sample, removal efficiency dropped to $67 \%$. This decrease might be due to the reaction occurring between the acid and the metal oxides on the adsorbent surface, reaction products blocking the pores of the diatomite, thereby reducing adsorption efficiency [25].

Thermo-chemical treatment of the raw diatomite did not show a positive trend on improving its adsorption capacity, Figure $5 \mathrm{c}$. The removal efficiency values decreased from 71 to $57 \%$ for $D$ and D-750-2M, respectively.

In the case of ultrasonic treatment, increasing of power and treatment time led to the same trend in removal efficiency evolution, Figures $5 \mathrm{~d}$ and $5 \mathrm{e}$. The best results, with a removal efficiency of $76 \%$ were obtained in case of both D-100-10 and D-120-8 samples. Further increase of time (>10 min) and power $(>120 \mathrm{~W})$ could have as a result pores destruction and therefore a decrease in removal efficiency values. Between the best results obtained for various treatments, Figure 6 , slight improvements in terms of removal efficiency by comparison with $D$ sample were obtained just for D-250-2, D-2M, D-100-10, and D-120-8 samples. 

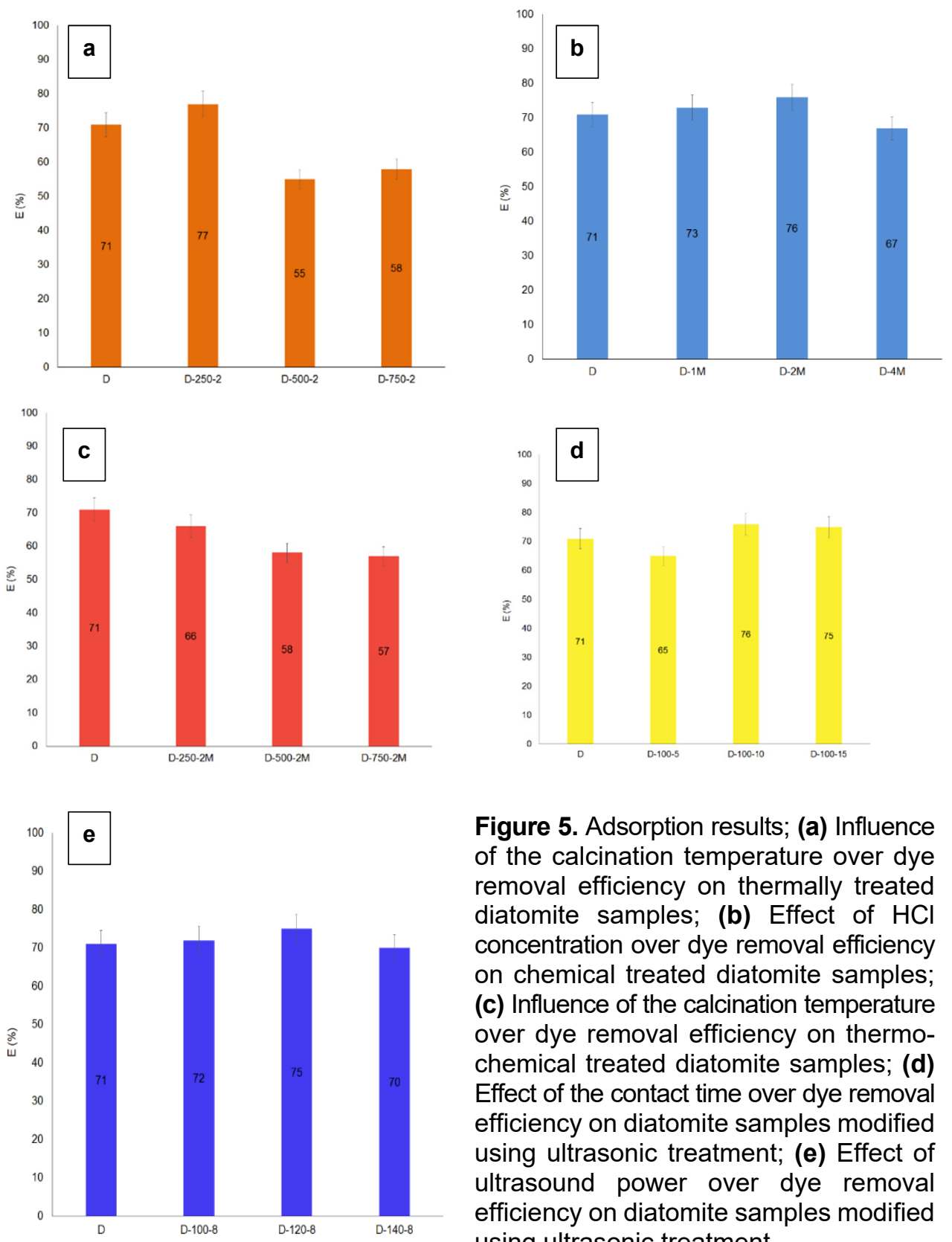

Figure 5. Adsorption results; (a) Influence of the calcination temperature over dye removal efficiency on thermally treated diatomite samples; (b) Effect of $\mathrm{HCl}$ concentration over dye removal efficiency on chemical treated diatomite samples; (c) Influence of the calcination temperature over dye removal efficiency on thermochemical treated diatomite samples; (d) Effect of the contact time over dye removal efficiency on diatomite samples modified using ultrasonic treatment; (e) Effect of ultrasound power over dye removal efficiency on diatomite samples modified using ultrasonic treatment. 


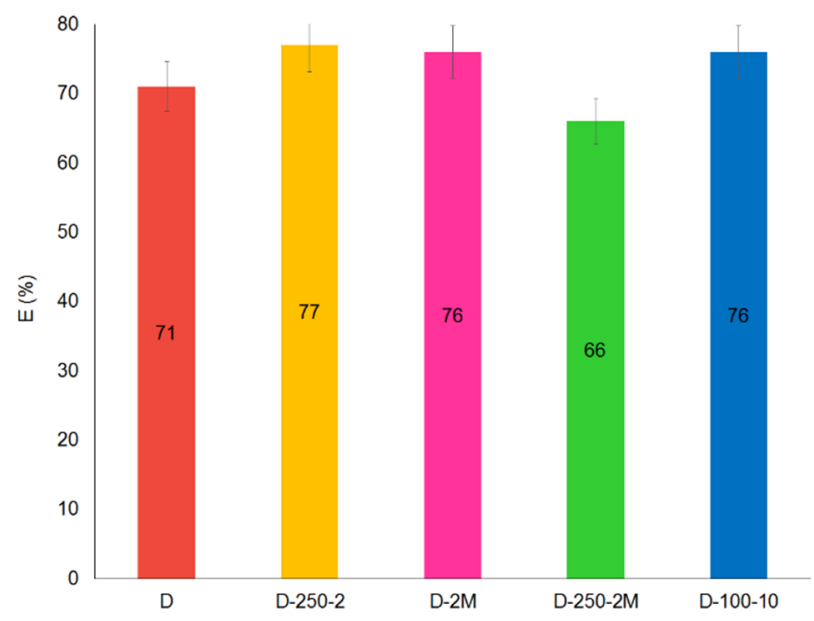

Figure 6. Comparison of the maximum removal efficiencies obtained for each considered treatment.

\section{Adsorbent regeneration}

The regeneration methods used on spent diatomite samples as described in the Experimental section, proved to have similar results when temperature and acid were used. Thermal treatment at $500^{\circ} \mathrm{C}$ and repeated contact with $\mathrm{HCl}$ led to a drastically decrease of removal efficiency $(52 \%)$ after the third regeneration-adsorption cycle, Figure 7.

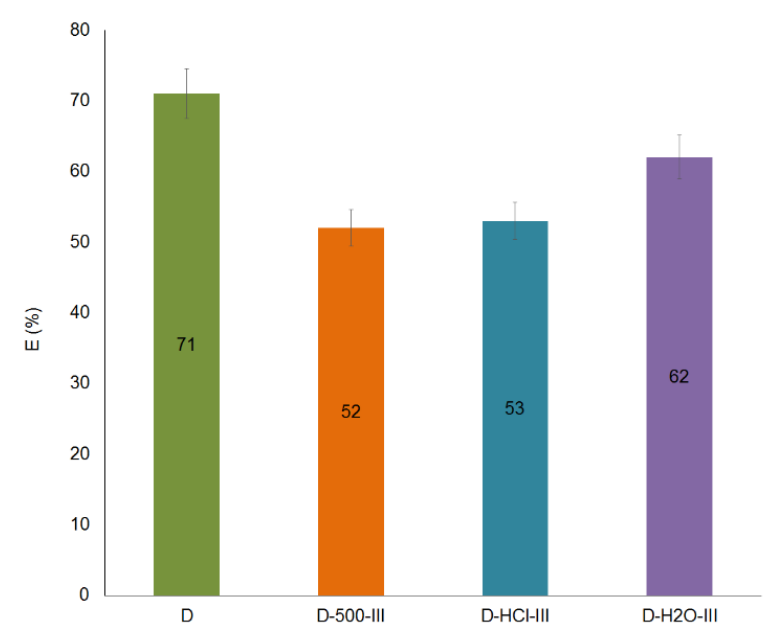

Figure 7. Effect of the regeneration method over dye removal efficiencies obtained after the third regeneration-adsorption cycle. 
These two methods are quite expensive and have a high environmental impact. In the case of water, a slower decrease in removal efficiency was recorded, 69,65 , and $62 \%$ after the first, second, and third regeneration cycle, respectively. Depending on the dye concentration present in water and considering that diatomite is a low-cost material, usage up to 3-5 cycles with water as a regeneration agent could be a promising process for colored wastewater treatment. When studied only thermal regeneration $\left(300-900^{\circ} \mathrm{C}\right)$, Auguedal et al. found that at $600^{\circ} \mathrm{C}$, the adsorbed Red ETL dye was completely removed, and around $73 \%$ was restored after three regeneration cycles [26].

\section{Adsorption kinetics}

Several adsorption kinetic models, such as pseudo-first- (Lagergren), pseudo-second-order, liquid film, and intra-particle diffusion models, (equations are presented in Table 2), were used to test experimental data in order to investigate the adsorption mechanism and potential rate determining steps [27-30]. The pore diffusion coefficient, $D\left(\mathrm{~cm}^{2} / \mathrm{s}\right)$ was also calculated (assuming a spherical geometry of the adsorbents - average size $0.1 \mathrm{~cm}$ ) using the following equation $[31,32]$ :

$$
D=0.003 \cdot \frac{r_{0}^{2}}{t_{0.5}}
$$

Based on the pseudo-second-order model, $\mathrm{t}_{0.5}$ was estimated using equation [32,33]:

$$
t_{0.5}=\frac{1}{k_{2} q_{e}}
$$

Time evolution of TB concentration for D and D-250-2 samples, Figure 8 , shows that the removal process takes place with a relatively small rate and the equilibrium was reached after about $300 \mathrm{~min}$.

The results obtained for all considered models are presented in Table 2. The pore diffusion coefficients are $7.93 \times 10^{-8}$ and $2.67 \times 10^{-8} \mathrm{~cm}^{2} / \mathrm{s}$ for $D$ and D-250-2, respectively, higher values than rate determining range $\left(10^{-11}-10^{-13}\right.$ $\mathrm{cm}^{2} / \mathrm{s}$ ) [33]. Taking into consideration all the calculated values, regression coefficient $\left(R^{2}\right)$ values, the fact that in the case of liquid film model the intercepts have values very close to 0 [34], Table 2, and also the shape of the time evolution curve (Figure 8 ), we have concluded that in this particular case, liquid film diffusion could be rate-determining step. 
Table 2. Pseudo-first-, pseudo-second-order, intra-particle, and liquid film diffusion parameters for TB adsorption onto D and D-250-2 samples.

\begin{tabular}{|c|c|c|c|c|c|c|c|}
\hline \multirow{3}{*}{$\begin{array}{l}\text { Diatomite } \\
\text { sample }\end{array}$} & \multicolumn{4}{|c|}{ Pseudo-first-order } & \multicolumn{3}{|c|}{ Pseudo-second-order } \\
\hline & \multicolumn{4}{|c|}{$\begin{array}{c}\ln \left(q_{e}-q_{t}\right)=\ln q_{e}-k_{2} \cdot t \\
{[27]}\end{array}$} & \multicolumn{3}{|c|}{$\frac{t}{q_{t}}=\frac{1}{k_{2} \cdot q_{e}^{2}}+\frac{t}{q_{e}}$} \\
\hline & $q_{e, \exp }$ & $\mathbf{k}_{1}$ & $q_{e, c a l}$ & $\mathbf{R}^{2}$ & $k_{2}$ & $q_{e, c a l}$ & $\mathbf{R}^{2}$ \\
\hline D & 7.39 & 0.0112 & 9.394 & 0.9525 & 3.0790 & 13.45 & 0.9816 \\
\hline \multirow[t]{3}{*}{ D-250-2 } & 7.97 & 0.0124 & 10.29 & 0.9335 & 5.0937 & 12.24 & 0.9945 \\
\hline & \multicolumn{4}{|c|}{ Intra-particle diffusion } & \multicolumn{3}{|c|}{ Liquid film diffusion } \\
\hline & \multicolumn{4}{|c|}{$\begin{array}{c}q_{t}=k_{i p} \cdot t^{0.5} \\
{[29]}\end{array}$} & \multicolumn{3}{|c|}{$\begin{array}{c}\ln (1-F)=-k_{f d} \cdot t \\
{[30]}\end{array}$} \\
\hline D & \multicolumn{2}{|c|}{0.5086} & -1.1903 & 0.9966 & 0.0112 & -0.2403 & 0.9525 \\
\hline D-250-2 & \multicolumn{2}{|c|}{0.0119} & 1.6859 & 0.9518 & 0.0124 & -0.2558 & 0.9335 \\
\hline
\end{tabular}

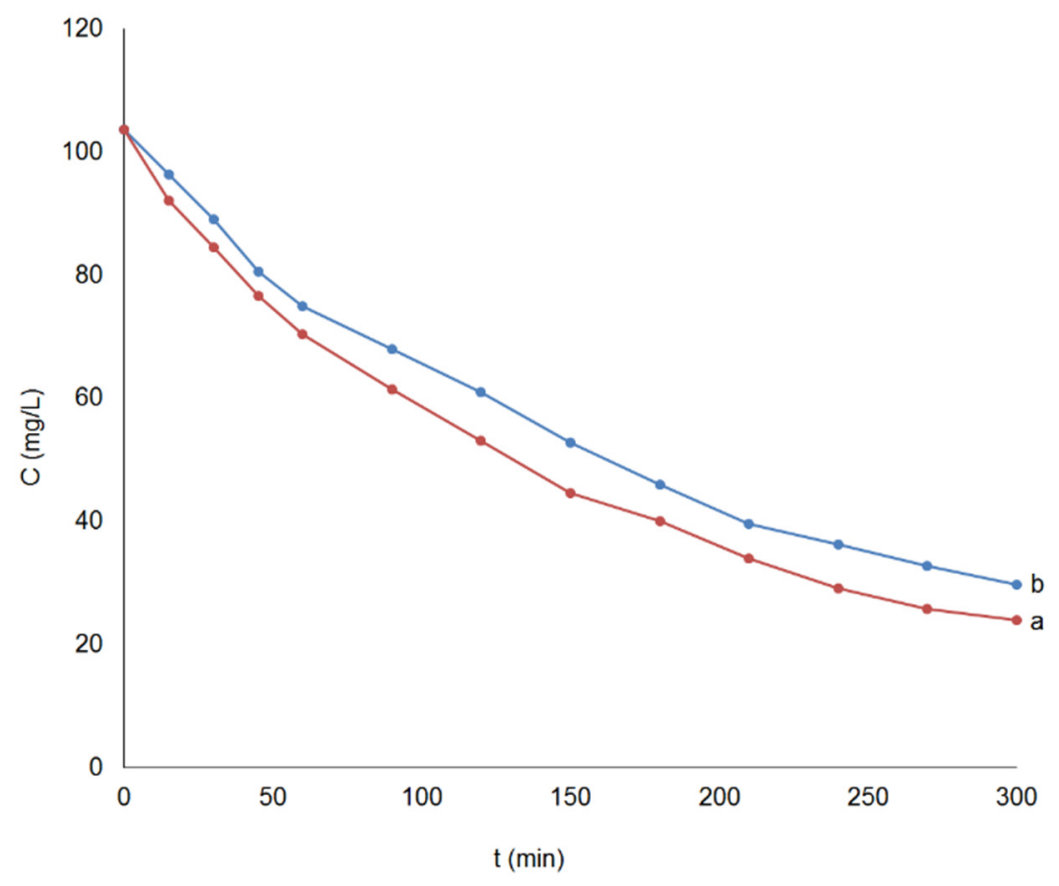

Figure 8. Time evolution of TB concentration for adsorption on (a) D and (b) D-250-2 diatomite samples. 


\section{CONCLUSIONS}

A Romanian diatomite sample subjected to various treatments (thermal, chemical, thermo-chemical, and ultrasonic) was tested for the removal of toluidine blue cationic dye from aqueous solutions. XRD, FTIR, and SED-EDX analyses confirmed the siliceous nature of the diatomaceous material, presence of the pennate frustules of diatoms, and the small amount of impurities. Between the considered treatments applied to the raw diatomite, improvements in terms of adsorption capacity and removal efficiency were obtained in case of: D-250-s (7.97 mg/g and 77\%), D-2M and D-120-8 $(7.85 \mathrm{mg} / \mathrm{g}$ and $75 \%)$, and D-100-10 (7.93 mg/g and $76 \%)$ by comparison with D $(7.39 \mathrm{mg} / \mathrm{g}$ and $71 \%$ ). Regeneration of the diatomite samples was realized using thermal, acid, and water methods. The results showed that when the regeneration was realized with water, the smallest decrease in removal efficiency was obtained even after three regeneration-adsorption cycles (a drop of $13 \%$ by comparison with thermal regeneration where a $27 \%$ drop was recorded). The calculated data showed that liquid film diffusion might be rate-determining step in this case.

To answer the question from the title, besides the $2 \mathrm{~h}$ at $250^{\circ} \mathrm{C}$ treatment, the slight improvement in adsorption capacities and efficiency obtained for all the other treatments do not justify the costs of these treatments.

\section{EXPERIMENTAL}

\section{Materials}

Diatomite sample (raw diatomite) collected from Minișul de Sus deposit, Arad County, Romania was used as an adsorbent in this study. Characterization of diatomite was realized using X-ray diffraction (XRD), scanning electron microscopy (SEM), X-ray photoelectron spectroscopy (EDX), and Fourier Transformed Infrared Spectroscopy (FTIR).

Toluidine Blue, $\mathrm{C}_{15} \mathrm{H}_{16} \mathrm{CIN}_{3} \mathrm{~S} \cdot 0.5 \mathrm{ZnCl}_{2}, 373.97 \mathrm{~g} / \mathrm{mol}$, TB (Sigma Aldrich) was used as model dye molecules for the adsorption processes. A stock solution of $1000 \mathrm{mg} / \mathrm{L}$ was used to prepare the desired concentration $(100 \mathrm{mg} / \mathrm{L})$ solution.

\section{Adsorbent preparation}

Thermal, chemical, thermo-chemical, and ultrasonic treatments were applied to the raw diatomite sample. A total of 17 samples have been prepared as described below. 
Raw diatomite was first subjected to a grinding process, followed by size separation to obtain the $0.6-1.0 \mathrm{~mm}$ fraction, which was further used throughout the experiments. Raw diatomite was then washed a few times with distilled water in order to remove fine particles and dried at $105^{\circ} \mathrm{C}$ for $24 \mathrm{~h}$.

Thermal treatment was realized through calcination at different temperatures in $250-750^{\circ} \mathrm{C}$ interval for 1,2 , and $4 \mathrm{~h}$, modified after Aivalioti et al. [12,13]. Five thermal modified samples were obtained, Table 3.

Chemical treatment was performed using $\mathrm{HCl}$ solution of different concentrations ( $1 \mathrm{M}, 2 \mathrm{M}$, and $4 \mathrm{M}$ ), modified after Zhang et al. [25]. Raw diatomite and acid solution were contacted at room temperature under mechanical stirring $(300 \mathrm{rpm})$ for $3 \mathrm{~h}$ at a solid:liquid ratio of 1:10. The obtained samples were separated from the acid solution, thoroughly washed with distilled water until no chlorine was detected $\left(\mathrm{AgNO}_{3} 0.01 \mathrm{~N}\right)$ and dried at $105^{\circ} \mathrm{C}$ for $24 \mathrm{~h}$, Table 3 .

Thermo-chemical treatment was achieved using a chemical treated sample $(\mathrm{HCl} 2 \mathrm{M}$, as described above) subsequently calcined at 250,500 , and $750^{\circ} \mathrm{C}$ for $2 \mathrm{~h}$, Table 3 .

Ultrasonic treatment, modified after Zhang et al. [25], was realized using power settings in 100-180 W interval and contact time of 5 to $15 \mathrm{~min}$ as follows: $20 \mathrm{~g}$ of raw diatomite and $100 \mathrm{~mL}$ distilled water were added in a glass beaker, which was then placed in an ultrasonic bath at room temperature at an established power and time interval. The solid was recovered by settling, washed with distilled water and dried at $105^{\circ} \mathrm{C}$ for 24 h. Six samples were thus obtained, Table 3.

\section{Adsorbent characterization}

XRD analyses of diatomite samples were performed using a D8 ADVANCE Bruker diffractometer, CuK $\alpha$ anticathode. The diffractograms were recorded from $5^{\circ}$ to $80^{\circ}, 2 \theta$ degree. The analytic conditions were 40 $\mathrm{kV}, 40 \mathrm{~mA}$, and a step of 0.02 degrees $/ \mathrm{min}$.

SEM-EDX analyses were performed using a JEOL JSM-6510 and Bruker EDX equipment. Prior to scanning, the diatomite sample was mounted on a stainless-steel slab with double stick tape and coated with a thin layer of gold in high vacuum condition.

FTIR analyses were performed on dried samples prepared by encapsulating $1.2 \mathrm{mg}$ of finely grounded particles in $300 \mathrm{mg}$ of $\mathrm{KBr}$. Infrared spectra were obtained using a JASCO 615 FTIR spectrometer $400-4000 \mathrm{~cm}^{-1}$ (resolution, $2 \mathrm{~cm}^{-1}$ ). 


\section{Adsorption experiments}

TB adsorption process was conducted in batch conditions, in a thermostated batch reactor placed on a shaker (50 rpm), using $1 \mathrm{~g}$ adsorbent (0.6-1.0 mm grain size), $100 \mathrm{~mL}$ dye solution $(100 \mathrm{mg} / \mathrm{L})$, at $20 \pm 2^{\circ} \mathrm{C}$. Working conditions were selected based on preliminary experimental results. Dye concentration from solution was determined using a UV-Vis Jenway 6305 spectrophotometer (calibration curve 2-10 mg/L) at the maximum absorption wavelength of $\lambda_{\mathrm{TB}}=633 \mathrm{~nm}$. Experiments were conducted in the same conditions for all diatomite samples considered. The evolution and effectiveness of the dye adsorption process were evaluated by means of the amount of dye adsorbed, q (mg/g) and removal efficiency, E (\%) [35].

\section{Adsorbent regeneration}

Although diatomite is a low-cost material, there might be instances when regeneration and/or dye recovery will be required. Therefore, this study considered the potential reuse of the spent diatomite, proposing three regeneration methods for the raw diatomite, namely: thermal, acid, and water, Table 4. In case of acid $(\mathrm{HCl})$ and water (distilled) regeneration, diatomite was contacted with the liquid using a solid:liquid ratio of 1:10, under continuous stirring (shaker) at $50 \mathrm{rpm}$ for $5 \mathrm{~h}$. Three regeneration-adsorption cycles were realized in each case.

Table 3. Diatomite treatments and samples labeling.

\begin{tabular}{|c|c|c|c|c|}
\hline Treatment & Label & \multicolumn{3}{|c|}{ Parameter } \\
\hline Raw & D & \multicolumn{3}{|c|}{ grinding / size separation / washing } \\
\hline \multirow{6}{*}{ Thermal } & & \multicolumn{2}{|c|}{ Temperature $\left({ }^{\circ} \mathrm{C}\right)$} & Time $(\mathrm{h})$ \\
\hline & $\mathrm{D}-250-2$ & \multicolumn{2}{|c|}{250} & 2 \\
\hline & D-500-1 & \multicolumn{2}{|l|}{500} & 1 \\
\hline & D-500-2 & \multicolumn{2}{|l|}{500} & 2 \\
\hline & D-500-4 & \multicolumn{2}{|l|}{500} & 4 \\
\hline & $\mathrm{D}-750-2$ & \multicolumn{2}{|l|}{750} & 2 \\
\hline \multirow{4}{*}{ Chemical } & & \multicolumn{3}{|c|}{$\mathrm{HCl}$ concentration (M) } \\
\hline & D-1M & \multicolumn{3}{|c|}{1} \\
\hline & D-2M & \multicolumn{3}{|c|}{2} \\
\hline & $\mathrm{D}-4 \mathrm{M}$ & \multicolumn{3}{|c|}{4} \\
\hline \multirow{4}{*}{$\begin{array}{l}\text { Thermo- } \\
\text { chemical }\end{array}$} & & Temperature $\left({ }^{\circ} \mathrm{C}\right)$ & Time (h) & $\mathrm{HCl}$ concentration (M) \\
\hline & D-250-2M & 250 & 2 & 2 \\
\hline & D-500-2M & 500 & 2 & 2 \\
\hline & D-750-2M & 750 & 2 & 2 \\
\hline
\end{tabular}




\begin{tabular}{|c|c|c|c|}
\hline \multirow{4}{*}{ Ultrasonic } & & Power (W) & Time (min) \\
\cline { 2 - 4 } & $\mathrm{D}-100-5$ & 100 & 5 \\
\cline { 2 - 4 } & $\mathrm{D}-100-10$ & 100 & 10 \\
\cline { 2 - 4 } & $\mathrm{D}-100-15$ & 100 & 15 \\
\cline { 2 - 4 } & $\mathrm{D}-100-8$ & 100 & 8 \\
\cline { 2 - 4 } & $\mathrm{D}-120-8$ & 120 & 8 \\
\cline { 2 - 4 } & $\mathrm{D}-140-8$ & 140 & 8 \\
\hline
\end{tabular}

Table 4. Spent diatomite regeneration; type, samples labeling, and removal efficiencies.

\begin{tabular}{|c|c|c|c|c|}
\hline Regeneration & Label & $\begin{array}{l}\text { Regeneration } \\
\text { parameters }\end{array}$ & $\begin{array}{l}\text { Regeneration- } \\
\text { adsorption cycle }\end{array}$ & $\begin{array}{c}E \\
(\%)\end{array}$ \\
\hline Raw & $D$ & - & & 71 \\
\hline \multirow{3}{*}{ Thermal } & D-500-I & \multirow{3}{*}{$500^{\circ} \mathrm{C}, 2 \mathrm{~h}$} & 1 & 58 \\
\hline & D-500-II & & II & 54 \\
\hline & D-500-III & & III & 52 \\
\hline \multirow{3}{*}{ Acid } & D-HCl-I & \multirow{3}{*}{$\mathrm{HCl} 2 \mathrm{M}, 5 \mathrm{~h}$} & $\mathrm{I}$ & 65 \\
\hline & $\mathrm{D}-\mathrm{HCl}-\mathrm{II}$ & & II & 55 \\
\hline & D-HCl-III & & III & 53 \\
\hline \multirow{3}{*}{ Water } & $\mathrm{D}-\mathrm{H}_{2} \mathrm{O}-\mathrm{I}$ & \multirow{3}{*}{$\mathrm{H}_{2} \mathrm{O}, 50^{\circ} \mathrm{C}, 5 \mathrm{~h}$} & I & 69 \\
\hline & $\mathrm{D}-\mathrm{H}_{2} \mathrm{O}-\mathrm{II}$ & & II & 65 \\
\hline & $\mathrm{D}-\mathrm{H}_{2} \mathrm{O}-\mathrm{III}$ & & III & 62 \\
\hline
\end{tabular}

\section{Abbreviations}

$\mathrm{C}_{\mathrm{e}}$ - concentration of dye at equilibrium $(\mathrm{mg} / \mathrm{L})$

$\mathrm{D}$ - pore diffusion coefficient $\left(\mathrm{cm}^{2} / \mathrm{s}\right)$

$\mathrm{E}$ - removal efficiency (\%)

$\mathrm{F}-$ fraction attainment at equilibrium $\left(=\mathrm{q}_{\mathrm{t}} / \mathrm{q}_{\mathrm{e}}\right)$

$\mathrm{k}_{1}$ - pseudo-first-order rate constant $(1 / \mathrm{min})$

$\mathrm{k}_{2}$ - pseudo-second-order rate constant $(\mathrm{g} / \mathrm{mg} \cdot \mathrm{min})$

$\mathrm{k}_{\mathrm{fd}}-$ liquid film diffusion rate constant $(1 / \mathrm{min})$

$\mathrm{k}_{\mathrm{ip}}$ - intra-particle diffusion rate constant $\left(\mathrm{mg} / \mathrm{g} \cdot \mathrm{min}^{0.5}\right)$

$\mathrm{q}$ - the amount of dye adsorbed $(\mathrm{mg} / \mathrm{g})$

$\mathrm{q}_{\mathrm{e}}$ - the amount of dye adsorbed at equilibrium - adsorption capacity $(\mathrm{mg} / \mathrm{g})$

$\mathrm{q}_{\mathrm{e}, \exp }$ - the experimental amount of dye adsorbed at equilibrium $(\mathrm{mg} / \mathrm{g})$

$\mathrm{q}_{\mathrm{e}, \mathrm{cal}}$ - the calculated amount of dye adsorbed at equilibrium $(\mathrm{mg} / \mathrm{g})$

$\mathrm{q}_{\mathrm{t}}$ - the amount of dye adsorbed at time $\mathrm{t}(\mathrm{mg} / \mathrm{g})$

$r_{0}$ - diatomite grain diameter $(\mathrm{cm})$

$\mathrm{t}$ - time (min)

$t_{0.5}-$ time for half adsorption (s) 


\section{REFERENCES}

1. E. Erdem; G. Çölgeçen; R. Donat; J. Colloid Interf. Sci., 2005, 282, 314-319.

2. M. Toor; B. Jin; S. Dai; V. Vimonses; J. Ind. Eng. Chem., 2015, 21, 653-661.

3. J.X. Lin; S.L. Zhan; M.H. Fang; X.Q. Qian; J. Porous Mat. 2007, 14, 449-455.

4. E. Bulut, M. Özacar; I. A. Şengil; J. Hazard. Mater., 2008, 154, 613-622.

5. L. Lian; L. Guo; C. Guo; J. Hazard. Mater., 2009, 161, 126-131.

6. P. Moslehi; P. Nahid; Int. J. Eng., Transactions B: Applications, 2007, 20, 141-146.

7. M.A.M.M. Khraisheh; Y.S. Al-Degs; W.A.M. Mcminn; Chem. Eng. J., 2004, 99, 177-184.

8. V.C. Brana; C. Avramescu; I. Călugăru; Substanţe minerale nemetalifere, Editura Tehnică, Bucureşti, 1986, pp. 133-135.

9. A. Sari; D. Çitak; M. Tuzen; Chem. Eng. J., 2010, 162, 521-527.

10. M.A. Al-Ghouti; M.A.M. Khraisheh; S.J. Allen; M.N. Ahmad; J. Environ. Manage., 2003, 69, 229-238.

11. M.A.M.M. Khraisheh; M.A. Al-Ghouti; S.J. Allen; M.N. Ahmad; Water Res., 2005, 39, 922-932.

12. M. Aivalioti; I. Vamvasakis; E. Gidarako; J. Hazard. Mater., 2010, 178, 136-143.

13. M. Aivalioti; P. Papoulias; A. Kousaiti; E. Gidarakos; J. Hazard. Mater., 2012 207-208, 117-127.

14. W. Zhaolun; Y. Yuxiang; Q. Xuping; Z. Jianbo; C. Yaru; N. Linxi; Environ. Chem. Lett., 2005, 3, 33-37.

15. W.-T. Tsai; C.-W. Lai; K.-J. Hsien; J. Colloid Interf. Sci., 2006, 297, 749-754.

16. Z. Al-Qodah; W.K. Lafi; Z. Al-Anber; M. Al-Shannag; A. Harahsheh; Desalination, 2007, 217, 212-224.

17. E.A. Mohamed; A.Q. Selim; A.M. Zayed; S. Komarneni; M. Mobarak; M.K. Seliem; J. Colloid Interf. Sci., 2019, 534, 408-419.

18. J. Zhang Jian; Q. Ping; M. Niu; H. Shi; N. Li; Appl. Clay Sci, 2013, 83-84, 12-16.

19. S.D.J. Inglethorpe; Industrial minerals, Laboratory manual: Diatomite, BGS Technical Report WG/92/39, 1993.

20. N. Inchaurrondo; J. Font; C.P. Ramos; P. Haure; Appl. Catal. B, 2016, 181, 481494.

21. H. Liang; S. Zhou; Y. Chen; F. Zhou; C. Yan; J. Taiwan Inst. Chem. Eng., 2015, 49, 105-112.

22. W. Tang; K. Qiu; P. Zhang; X. Yuan; Appl. Surf. Sci., 2016, 362, 545-550.

23. T. Qian; J. Li; X. Min; Y. Deng; W. Guan; L. Ning; Energ. Convers. Manage., 2015, 98, 34-45.

24. S.S. Ibrahim; A.Q. Selim; Physicochem. Probl. Mi., 2012, 48(2), 413-424.

25. G.Zhang; D. Cai; M. Wang; C. Zhang; J. Zhang; Z. Wu; Micropor. Mesopor. Mat., 2013, 165, 106-112.

26. H. Aguedal; A. Iddou; A. Aziz; A. Shishkin; J. Ločs; T. Juhna; Int. J. Environ. Sci. Technol., 2019, 16, 113-124.

27. S. Lagergren; Kungl. Svenska Vetenskapsakad. Handl., 1898, 24, 1-39. 
28. Y.S. Ho; G. McKay; Process Saf. Environ., 1998, 76, 332-340.

29. W.J. Weber; J.C. Morris; J. Sanit. Eng. Div. ASCE, 1963, 89, 31-60.

30. G.E. Boyd; A.W. Adamson; L.S. Myers Jr.; J. Am. Chem. Soc., 1947, 69, 28362848.

31. V. Srihari; A. Das; Desalination, 2008, 225, 220-234.

32. X.-Y. Pang; F. Gong; E-J. Chem., 2008, 5, 802-809.

33. L.C. Cotet; A. Măicăneanu; C.I. Fort; V. Danciu; Sep. Sci. Technol., 2013, 48, 2649-2658.

34. N. Caliskan; A.R. Kul; S. Alkan; E.G. Sogut; I. Alacabey, J. Hazard. Mater., 2011, 193, 27-.

35. D.M. Gligor; A. Măicăneanu, Applications of Clay Minerals in Electrochemistry and Wastewater Treatment, in Clay: Types, Properties and Uses, J. P. Humphrey, D.E. Boyd) Eds.; Nova Science Publishers Inc., New York, 2011, Chapter 1, pp. 1-62. 
